\title{
LA ÉTICA PROFESIONAL DEL CONTADOR
}

\author{
ROSELLA URDANEGUI \\ - Profesora de Introducción a la Contabilidad \\ Dirección de Contabilidad y Administración \\ Facultad de Negocios, UPC
}

Mucho se ha escrito sobre la ética profesional del contador. Sin embargo, aún hay un largo camino por recorrer en la sensibilización de los contadores frente a los casos recurrentes de corrupción y fraude.

La Real Academia Española define la ética como "conjunto de normas morales que rigen la conducta de la persona en cualquier ámbito de la vida" y como "parte de la filosofía que trata del bien y del fundamento de sus valores".

Según estas definiciones, podríamos deducir que los comportamientos éticos siempre se darán de acuerdo con las normas morales, y que estas reflejan el bien común; es decir, no pensar en el bienestar individual sino en el interés público. También podemos señalar que una persona ética debe ser íntegra en cualquier aspecto de la vida, sea como profesional o como ciudadano.

Sin lugar a dudas, un comportamiento poco ético influye de forma determinante en el desarrollo de cualquier profesional. Pero, en el caso de los contadores, las repercusiones cobran mayor importancia al afectar al país en lo social y en lo económico. Es por ello que la profesión contable se rige por un código de ética, el cual sirve de guía moral y direcciona al contador hacia un desempeño transparente en el ámbito profesional, declarando con ello la intención de cumplir con la sociedad.

Definiendo la contabilidad como un sistema de información por medio del cual se procesan y analizan las transacciones de una empresa para posteriormente interpretar los resultados de los estados financieros para la toma de decisiones, podemos inferir que la profesión contable debe satisfacer las necesidades de información de diferentes agentes, como los inversionistas, la administración tributaria, proveedores o clientes, entre otros. Para ello, la profesión contable cuenta con principios básicos que deben estar presentes en todas y cada una de las actividades profesionales de un contador, entre las que se encuentran la objetividad o independencia de criterio, sin favorecer a nadie y primando el juicio profesional; la confidencialidad, sabiendo que se posee información que posiblemente pocas personas tienen y que debe permanecer resguardada (en otras palabras, saber conservar el secreto profesional); la confianza, que abarca la honestidad con que se desempeñan las labores (es decir, ser íntegros en nuestros actos); y por último, también muy importante, la competencia profesional, manteniendo los conocimientos profesionales actualizados con la rigurosidad que el mercado exige.

Los actos de corrupción que se suscitan y que han sido denunciados son algunas de las razones por las que la profesión contable ha perdido credibilidad. A pesar de que los contadores disponemos de las herramientas para identificar actos ilícitos como la doble contabilidad, la simulación de gastos no realizados o la falsificación de información en las empresas, muchos optan por esconder el delito y dejar pasar la situación.

La Federación Internacional de Contadores, tiene como misión "el desarrollo y fortalecimiento de la profesión contable a nivel mundial con estándares armonizados, capaces de proporcionar servicios de alta calidad a favor del interés público". Es así que los contadores ostentamos normas internacionales, las mismas que nos ayudan a homogeneizar criterios.

El contador tiene la responsabilidad de que los estados financieros contengan información transparente, real y oportuna. Cuando un contador trabaja en una empresa, es el encargado de supervisar el registro y control de las transacciones de acuerdo con las normas vigentes. Es de esperar, así, que siempre actúe de buena fe y con transparencia, y que, en caso de que encuentre alguna distorsión de la realidad, se comporte según los valores que la profesión exige. Para prevenir posibles actos ilícitos, este deberá diseñar e implementar, conjuntamente con otras autoridades de la empresa, diferentes actividades de control, para así aminorar los potenciales riesgos.

Los actos ilícitos existirán siempre, y cada vez se evidenciarán mediante mecanismos más sofisticados. Corresponde a las personas que tienen bajo su cargo las diferentes transacciones la responsabilidad de prevenirlos. En ese sentido, el contador será pieza fundamental para impedir estos actos, trabajando con objetividad, controlando las transacciones que efectúa la empresa y aplicando el sentido ético de manera natural y cotidiana durante su labor profesional. 